\title{
Connection control implications in a distributed plasticity cerebellar model
}

\author{
Niceto R Luque ${ }^{1 * \dagger}$, Jesús A Garrido ${ }^{2 \dagger}$, Richard R Carrillo ${ }^{1}$, Eduardo Ros $^{1}$ \\ From Twenty Second Annual Computational Neuroscience Meeting: CNS*2013 \\ Paris, France. 13-18 July 2013
}

The cerebellum is one of the parts of the brain which has aroused more curiosity amongst neuroscientists. Indeed, several forms of plasticity mechanisms have been reported at several sites of the cerebellar model circuitry, thus including plasticity mechanisms not just at parallel fibers (a well-accepted plasticity site) but also at synaptic inputs of deep cerebellar nuclei (DCN) (from mossy fibers (MFs) [1,2] and Purkinje cells (PCs) [3,4]). The Marr and Albus model already hypothesized that parallel fiber (PFs) $\rightarrow$ Purkinje cell synapses presented both long-term potentiation (LTP) [5,6] and long-term depression (LTD) [5-7] plasticity so as to correlate the activity at parallel fibers with the incoming error signal through climbing fibers. Nevertheless, in subsequent studies, it has been demonstrated that many sites in the cerebellum show traces of plasticity [8-10]. But the way in which those distributed plasticity mechanisms may improve the operational capabilities of the cerebellum is still an open issue.

In this work we propose that the synaptic plasticity of mossy-fiber-to-deep-cerebellar-nucleus-cell and Purkinjecell-to-deep-cerebellar-nucleus-cell may regulate the effect of Purkinje-cell activity on the cerebellar output, behaving as a distributed homeostatic mechanism [11]. The plasticity at the DCN afferents helps to keep the Purkinje-cell activity in an adequate range independently of the magnitude required for the cerebellar output, thus improving the precision of this output signal.

Since these plasticity mechanisms are capable of adapting the cerebellar behavior in the long-term, it is of necessity the presence of fast feedback for motor activities in order to perform precise movements. Thus,

\footnotetext{
* Correspondence: nluque@ugr.es

† Contributed equally

${ }^{1}$ Dept. of Computer Architecture and Technology. University of Granada,

Granada, Spain

Full list of author information is available at the end of the article
}

the presented work also explores the control implication that the inferior-olive-to-deep-cerebellar-nucleus-cell connection may possess in conjunction with the previously suggested plasticity mechanisms. As it is widely assumed, the climbing fiber activity that our cerebellar model implements is considered to be a teaching signal (targeting Purkinje cells). But we also explore its potential role as a control signal over the cerebellar output (targeting the deep cerebellar nuclei).

To investigate all these proposals, we have embedded the cerebellar model in a feed-forward control loop which is connected to a simulated 3-degree-of-freedom robot model.

\section{Author details}

${ }^{1}$ Dept. of Computer Architecture and Technology. University of Granada, Granada, Spain. ${ }^{2}$ Dept. of Brain and Behavioral Sciences. University of Pavia, Consorzio Interuniversitario per le Scienze Fisiche della Materia (CNISM), Pavia, Italy.

\section{Published: 8 July 2013}

\section{References}

1. Medina J, Mauk M: Simulations of cerebellar motor learning: computational analysis of plasticity at the mossy fiber synapse. J Neurosci 1999, 19(16):7140-51.

2. Pugh J, Raman I: Potentiation of mossy NMDA receptor activation followed by postinhibitory rebound current. Neuron 2006, 51(1):113-23.

3. Aizenman C, Manis $P$, Linden D: Polarity of long-term synaptic gain change is related to postsynaptic spike. Neuron 1998, 21(4):827-35.

4. Ouardouz M, Sastry B: Mechanisms underlying Itp of inhibitory synaptic transmission in the deep cerebellar nuclei. J Neurophysiol 2000, 84(3):1414-21.

5. Boyden ES, Katoh A, Raymond JL: Cerebellum-dependent learning: the role of multiple plasticity mechanisms. Annu Rev Neurosci 2004, 27:581-609.

6. Coesmans M, Weber J, De Zeeuw C, Hansel C: Bidirectional parallel plasticity in the cerebellum under climbing. Neuron 2004, 44(4):691-700.

7. Ito M, Kano M: Long-lasting depression of parallel fiber-Purkinje cell transmission induced by conjunctive stimulation of parallel fibers and climbing fibers in the cerebellar cortex. Neurosci Lett 1982, 33:253-258.

8. Hansel C, Linden DJ, D'Angelo E: Beyond parallel fiber LTD: the diversity of synaptic and non-synaptic plasticity in the cerebellum. Nat Neurosci 2001, 4:467-475. 
9. D'angelo E: Neural circuits of the cerebellum: Hypothesis for function. $J$ Int Neurosci 2011, 10(3):317-52.

10. Gao Z, van Beugen BJ, De Zeeuw Cl: Distributed Synergistic Plasticity and Cerebellar Learning. Nat Rev Neurosci 2012, 13:1-17.

11. Turrigiano GG, Nelson SB: Homeostatic plasticity in the developing nervous system. Nat Rev Neurosci 2004, 5:97-107.

doi:10.1186/1471-2202-14-S1-P329

Cite this article as: Luque et al: Connection control implications in a distributed plasticity cerebellar model. BMC Neuroscience 2013 14(Suppl 1):P329.

Submit your next manuscript to BioMed Central and take full advantage of:

- Convenient online submission

- Thorough peer review

- No space constraints or color figure charges

- Immediate publication on acceptance

- Inclusion in PubMed, CAS, Scopus and Google Scholar

- Research which is freely available for redistribution

Submit your manuscript at www.biomedcentral.com/submit
Ciomed Central 